\title{
Segmenting Medical Market Based on Banking Expectations: Evidence from Iran
}

\author{
- Azizi Shahriar, Hosseinabadi Vabid
}

\begin{abstract}
:
This research aims to identify banking expectations of the medical sector as one of the highincome sectors as a basis for segmenting the market. Mixed method (qual QUAN) design is used in this research. In qualitative phase 28 in-depth interviews with customers in medical sectors were competed. Using content analysis nine major expectations were identified which consisted of 24 sub-expectations. In quantitative phase data were collected by 456 questionnaires. Results revealed that major expectation of medical market are: check related services in the laboratory guild, loans in the pharmacy guild, and speed in the clinic guild. Segmentation showed three distinct segments: traditional, modern and low demanding. The results showed that laboratory and pharmacy guilds were almost similar to each other while the clinic guild had differences in comparison with the two other guilds.
\end{abstract}

Keywords: Expectation, Bank, Guild, Content Analysis, Segmentation

JEL Classification: G21, M31

\section{INTRODUCTION}

After the Islamic revolution, transferring the bank ownership to the government, we experienced a non-competitive market in the Iran banking industry for several years. But regarding the third five-year development plan (2000-2005) of, liberalization of the banking system was put on the agenda by founding of private banks. Entry of private banks and credit institutions as a new players and rapid growth of rival markets such as: gold and exchange market, real estate market, and remarkable technological progress on the other hand, have led to the formation of a variety of services such as credit cards, internet banking, mobile banking, etc. Accordingly, competition in this competitive industry has totally changed. In this dynamic and complex competitive environment, there is few creative new services. Rapid imitations in introducing new banking services is the vital strategy of Iranian banks. Financial institutions and banks are required to change their own way of reacting to the market. Such that they focus less on products and more on customers and relationships (Harrison, 2000; Adamson et al., 2003). With increasing competition, due to increased customer options, companies will succeed that are able to better understand and identify customer expectations and desired values and better respond to them, and can therefore survive (Wang \& Liao, 2007). The relationship between banks and customers is no more doing a series of simple transaction processes that they did in the past (Parasuraman et al., 1988); Solving customers' problems and meeting their expectations are of the major factors in market development and maintain customer loyalty. Unresolved problems impose a negative impacts on customer-Bank relationship. 
Customer experiences are transferred to other persons, and this word of mouth advertisement plays an influential role in individual's choice and continuing work with the banks. People are more willing to engage in negative word of mouth communications (Anderson, 1994; Gremler \& Gwinner, 2000). On the other side, losing a customer means losing all purchase flows that person could make during the time he was the customer of that product or service (Kotler, 2006); Reichheld (1996) noted that increase in profits of 25 to 95 percent can be achieved only with a 5\% increase in customer retention cost. Based on these reasons, banks should continuously identify the needs and expectations of their customers and target market and improve and develop their services with regard to the bank interests. Lam and Burton (2006) stated that customers and particularly business clients, who were traditionally reluctant to change their bank, are now more willing to change it in the current turbulent market in case they receive a better bid of service from another bank. This emphasizes on recognizing the expectations of customers by banks.

Guilds are one of the vital segment for Iranian banks. Hugh et al. estimated that banks, approximately serving 1.3 million institutions and guilds, averagely earn two to three times more than the average of retail customers (Howcroft et al., 2007). These type of customer often have special bank expectations because of their business model nature. They at least expect banks to consider them as their special customers (Adamson et al., 2003; Lam \& Burton, 2006; Zineldin, 1995). Since the professions in guilds are similar, these markets have a great importance for the banks that act as a business partner for customers (Madill et al., 2002). Accordingly, they can ensure their profitability and increase their market share by providing good services and attracting and keeping them in banks (Zineldin, 1995).

Tab. 1 - Number of guilds in the Iran. (Source: www.asnaf.ir)

\begin{tabular}{|c|c|c|}
\hline & Number of active guilds & Percentage to the total guilds \\
\hline Manufacturing sector & 411198 & 19.95 \\
\hline Distribution sector & 962566 & 46.71 \\
\hline Technical services & 423688 & 20.56 \\
\hline Service sector & 263036 & 12.76 \\
\hline Total sum & 2060488 & 100 \\
\hline
\end{tabular}

One of the most important sectors of the guilds in Iran economy system is, medical sector including guilds of pharmacies, laboratories, and clinics. According to the Iran's Ministry of Health in 2012, there were 5023 laboratories, 8961 pharmacies and 31,891 clinics active in the country. These numbers constituted roughly $17 \%$ of total service sector guilds and was equivalent to $2.2 \%$ of all active trade unions work in the country. According to the Statistical Center of Iran, the health sector (including guilds of laboratories, pharmacies and clinics) produced an approximately 2200000000 us dollars added value in the national production in 2007, out of which an amount of 1205000000 US dollars belonged to the private sector. These numbers indicate the attractiveness of this sector for any Iranian banks. Given the very important and influential role of this sector in absorbing funds for banks and the literature weaknesses regarding specific expectations of this segment, this study attempts to identify banking expectations of the medical segment. Results of this study contributes banks and financial institutions to increase their market share in these segment. 


\section{THEORETICAL FOUNDATIONS}

\subsection{Segmentation}

Market segmentation for organizations in all sectors, has been central to marketing strategy (Weinstein, 2004). Segmentation is based on the assumption that the market is not homogeneous in terms of the consumer needs. Therefore, there are different segments of customers where individuals' within a segment have similar behaviors (Beane \& Ennis, 1987). Wendell Smith (1956) defined market segmentation as viewing a heterogeneous market that divided to a number of smaller homogeneous markets. According to Kotler and Armstrong (2010), market segmentation is defined as dividing it into distinct groups of buyers who are looking for separate goods or marketing mix elements. For usefulness of the results of a segmentation study, the segments must have the following properties: measurability, accessibility, considerable volume and profitability, and possibility of running more effective programs to attract and serve that sector (Kotler \& Armstrong, 2010). Customer segmentation has different bases. Punj and Stewart (1983) classified segmentation bases into two categories including: general variables such as age, gender, marital status, etc. and the category of product and purchase details including purchase history, how to pay money and the type of requested product. They added that the combination of these two variables offers a comprehensive segmentation. Kotler and Keller (2012) divided the variables of market segmentation into four categories of geographic, demographic, psychographic and behavioral characteristics for consumer markets. In the case of business to business marketing they also divided the market segmentation variables into demographic, operating variables, purchasing approaches, situational factors and personal characteristics for business markets. As competition in bank industry has been intensified, financial service institutions and banks have increasingly adopted a strategy based on sophisticated form of segmentation (Alfansi \& Saegeant, 2000). Machauer and Morgner (2001) stated that most banks still define their customers based on socio-economic and demographic characteristics, especially geographical and income related properties.

\subsection{Research Background}

No similar research was found regarding expectations of guilds in the banking industry in scientific various databases. Most of the research close to this subject were in the field of identifying expectations of small and medium enterprises SME. In addition, such expectations are not considered particularly for a specific industry or sector.

Based on depth interviews, Lam and Burton (2006) introduced the factors affecting loyalty of SMEs to the bank. These include: offering efficient and high-speed services, providing import and export services, insurance, stability in the policies of the bank and the bank manager (branch), efficient monetary and credit services, good communication with bank employees, variety of provided services and the perceived risk.

Marinkovic and Senic (2012) discovered three general factors as a banking service expectations of medium and small institutions in the form of 21 measures. The results showed that the first factor is the customer respect and understanding, which includes measures such as personal attention to clients, bank staff courtesy, Respect for clients, Understanding financial needs of cli- 
ents, etc. The second factor is professionalism, which includes variables such as accuracy of the delivered service, promptness in providing a service, employee appearance, etc. The third factor of this analysis is image that included variables such as bank image, branch image, modern equipment and its image compared to the competitors. In general, about $67 \%$ of the total variance is defined by these three dimensions. It is also suggested that the first two dimensions reflect the intangible effects of banking service offers, and the image dimension includes tangible quality factors. Financial factors are not analyzed at the micro level and may include loan rates, payment cards, availability, ability to manage the loans and the loan collaterals. Nielson et al. (1998) examined the business institutions' expectations from the banks and mentioned the following factors as their main expectations: Long-term relationship, competitive prices for services, efficient operations, accommodate credit needs. Other factors are placed second in importance and include: bank's knowledge of industry and market, personal relationship, convenient location, delivery of services, quick decisions, financially health, creativity, and new technologies. This is while the bankers thought that the most important expectation of business customers is competitive prices and this was very different with the expectation limit the customers had.

Azizi et.al (2014) based on mixed method design (qual QUAN) identified five factors for segmenting retail internet banking customer of Iranian banks by exploratory factor analysis. These factors include: ease of use, service diversity, security, speed and reliability. They found six distinct segments based on the factors. Charon et al (1989) used two board classes of variables to segment commercial market in banks.

Through interviews with managers of small enterprises, Howcroft et al. (2007) identified the banking expectations. In this qualitative study, they identified the following factors as the least important ones: offering specialized banking service packages for small business customers, transparency and greater use of people's everyday language rather than financial technical terms, importance of compliance with their profession and service, and customer-centric services of bank employees, perceived support both in the beginning and in case of problem occurrence and finally, cost of the provided services. This study refers to the notion that banks should have a life cycle perspective towards their business customers; because awareness of the business customers' stage of life will help the banks to provide appropriate financial and strategic advices to the customers. This research also expressed that internet banking, though considered as a good tool by everyone, is resisted by small business customers due to the following reasons: fear of internet security, non-appropriateness for solving complex problems and commercial crises. Also, they prefer social and personal relationships, especially when problems arise.

Using exploratory factor analysis, Narteh (2013) suggested that non retail customers consider the following factors when choosing the bank to open an account: price competitiveness, credit availability, perceived service quality, staff attributes and bank attributes. Other factors that the bank should provide as core services to them include services such as loans and overdrafts, cash collection, transfers, bank guarantees, advisory services and training. 
Tab. 2 - Expectations identified in past studies. (Source: Authors)

\begin{tabular}{|c|c|}
\hline Researcher(s) & banking expectations \\
\hline Nielsen (1998) & $\begin{array}{l}\text { Long-term relationship, competitive prices for services, } \\
\text { efficient operations, accommodate credit needs, business } \\
\text { knowledge, interpersonal relationship, convenient location, } \\
\text { delivery of services, make decisions quickly, financially } \\
\text { health, new technology, innovative, etc. }\end{array}$ \\
\hline $\begin{array}{l}\text { Lam and Burton } \\
\qquad(2006)\end{array}$ & $\begin{array}{l}\text { accommodate and understand customer needs, efficiency } \\
\text { and attitude of service delivery, export and import banking } \\
\text { services, insurance, stability in the bank policy and preserv- } \\
\text { ing branch chief, effective monetary and credit services, } \\
\text { good relationship with the bank staff, variety of services, } \\
\text { perceived risk }\end{array}$ \\
\hline $\begin{array}{l}\text { Marinkovic and Senic } \\
\qquad(2012)\end{array}$ & $\begin{array}{l}\text { Respecting and understanding client (personal attention } \\
\text { towards customers, employees curtsey, understanding the } \\
\text { financial needs of staff, readiness to help customers, etc.), } \\
\text { professionalism (accuracy of delivered services, Prompt- } \\
\text { ness in providing a service, Respecting previously agreed } \\
\text { deadlines, etc.), image (bank image, branch image, modern } \\
\text { equipment, etc.) }\end{array}$ \\
\hline Howcroft et al (2007) & $\begin{array}{l}\text { special banking services package for the customers, trans- } \\
\text { parent and understandable answers, matching the service } \\
\text { with individuals' business, quality of bank employees, } \\
\text { perceived support, price of provided services }\end{array}$ \\
\hline Lundahl et al. (2009) & $\begin{array}{l}\text { Technical factors (Services and products offered by banks } \\
\text { such as the price of services and special services) Func- } \\
\text { tional factors (quality and delivery of products and services } \\
\text { such as personal relationships and support during difficult } \\
\text { times of the customers) }\end{array}$ \\
\hline Madill et al. (2002) & $\begin{array}{l}\text { Bank manger's management (Understanding the SME's } \\
\text { business, easy to get in touch with, flexibility, approach- } \\
\text { able, reliable, etc.), branch staff (having knowledge, rapid } \\
\text { response, attentive and responsive, etc.), policy and proce- } \\
\text { dures of the bank (credit providing, loans flexible structure, } \\
\text { supporting SME in good and difficult times, etc.) }\end{array}$ \\
\hline Narteh (2013) & $\begin{array}{l}\text { Selecting the bank (price competitiveness, credit avail- } \\
\text { ability, perceived service quality, staff attributes and bank } \\
\text { attributes), core service of bank (loans and overdrafts, cash } \\
\text { collection, transfers, bank guarantees, advisory services and } \\
\text { training) }\end{array}$ \\
\hline
\end{tabular}




\section{METHODOLOGY}

Mixed method research design used for doing the the study. Qual $>$ QUAN as a sequential design applied. At the qualitative step 28 in-depth interviews done with customers. Using content analysis bank expectations detected. In quantitative step 456 questionnaires (107 in the laboratory, 192 in the clinic and 157 in the pharmacy). Qualitative data analysis revealed detailed 24 expectations which classified into 9 major factors. Four points scales $(1=$ very little importance, 2 = little importance 3 = high importance, $4=$ very high importance) applied for measuring items. Using industry experts the content validity of questionnaire proved. Cronbach's alpha was equal to 0.674. This ratio is above 0.6 threshold (Sekaran, 2003). K-means method was used for clustering the customers.

\section{RESULTS}

\subsection{Qualitative Data Analysis: Identifying Banking Expectations}

In this section, we performed content analysis based on reading and re-reading the interview transcripts. Analysis showed twenty four banking expectations, then these expectations categorized in to nine major expectations. As stated in their interviews, these individuals did not evaluate e-banking infrastructure as appropriate. Accordingly, the infrastructure was classified into one category and diversity of e-banking services was classified in another category of factors.

Tab. 3 - Relative and absolute frequency of major and sub expectations of the medical sector based on interviews (Source: Authors)

\begin{tabular}{|c|c|c|c|}
\hline Sub expectations & Main expectation & $\begin{array}{l}\text { Absolute } \\
\text { frequency }\end{array}$ & $\begin{array}{l}\text { Relative } \\
\text { frequency }\end{array}$ \\
\hline \multirow{4}{*}{$\begin{array}{l}\text { Interaction with } \\
\text { special customers }\end{array}$} & $\begin{array}{l}\text { Conformation of services with financial } \\
\text { turnover and capacity of individual }\end{array}$ & 19 & 38.0 \\
\hline & Privacy of personal information & 15 & 30.0 \\
\hline & Exemption from paying banking services fees & 16 & 32.0 \\
\hline & Sum & 31 & \\
\hline \multirow{5}{*}{ Relationship } & $\begin{array}{l}\text { Promoting communication channels of the } \\
\text { bank }\end{array}$ & 11 & 16.2 \\
\hline & $\begin{array}{l}\text { Convincing answer of the bank to the ques- } \\
\text { tions and expectations }\end{array}$ & 12 & 17.6 \\
\hline & Close relationship with the Branch Chief & 20 & 29.4 \\
\hline & $\begin{array}{l}\text { Good dealing and respectful behavior of the } \\
\text { branch staff }\end{array}$ & 25 & 36.8 \\
\hline & Sum & 68 & \\
\hline
\end{tabular}




\begin{tabular}{|c|c|c|c|}
\hline \multirow{3}{*}{$\begin{array}{l}\text { Variety of banking } \\
\text { services }\end{array}$} & $\begin{array}{l}\text { Issuing and charging international credit cards } \\
\text { such as VISA and MASTER cards }\end{array}$ & 17 & 44.7 \\
\hline & $\begin{array}{l}\text { Providing a deposit account as a backup for } \\
\text { the current account }\end{array}$ & 21 & 55.3 \\
\hline & Sum & 38 & \\
\hline \multirow{2}{*}{ Access } & Branch closeness & 16 & 100 \\
\hline & Sum & 16 & \\
\hline \multirow{4}{*}{ Speed } & Non-attendance in the bank queue & 13 & 25.4 \\
\hline & Providing services quickly & 22 & 43.3 \\
\hline & $\begin{array}{l}\text { reducing administrative bureaucracy in receiv- } \\
\text { ing services }\end{array}$ & 16 & 31.3 \\
\hline & Sum & 51 & \\
\hline \multirow{3}{*}{ Loans } & Higher volume loans & 26 & 60.4 \\
\hline & longer time period to repayment & 17 & 39.6 \\
\hline & Sum & 43 & \\
\hline \multirow{3}{*}{ Check } & Credit in the current account & 17 & 53.1 \\
\hline & $\begin{array}{c}\text { Notification in arrival of issued checks for } \\
\text { clearance }\end{array}$ & 15 & 46.9 \\
\hline & Sum & 32 & \\
\hline \multirow{5}{*}{$\begin{array}{l}\text { Electronic Banking } \\
\quad \text { features }\end{array}$} & Security of electronic banking instruments & 16 & 30.7 \\
\hline & Speed of electronic banking instruments & 13 & 25.0 \\
\hline & Precision of e-banking instruments & 12 & 23.0 \\
\hline & $\begin{array}{l}\text { Simple design and non-complexity of internet } \\
\text { banking }\end{array}$ & 11 & 21.3 \\
\hline & Sum & 52 & \\
\hline \multirow{4}{*}{$\begin{array}{l}\text { Variety of electron- } \\
\text { ic banking services }\end{array}$} & Transferring money through internet bank & 15 & 39.5 \\
\hline & $\begin{array}{c}\text { receiving account balance and circulation } \\
\text { through internet bank }\end{array}$ & 12 & 31.6 \\
\hline & Check Management in internet bank & 11 & 28.9 \\
\hline & Sum & 38 & \\
\hline
\end{tabular}

According to table 3, loan related expectations is mentioned 43 times during the 28 interviews, 26 of which were about higher volume loan. This amount equaled to 60.4 percent of the relative frequency of the total major loan related expectations. Longer period of loans repayment with 17 frequency, constituted 39.6 percent of the relative frequency of the loan related expectations. The most frequent of major expectations was the communication need with 68 frequency among the respondents. 


\subsection{ANALYSIS OF QUANTITATIVE DATA}

\subsubsection{The Priorities of Banking Expectations among Medical Guilds}

One sample t-test used to check whether the expectations were important in view of the guilds or not. Results (tables 4) show that only variety of e-banking services is below the mean. A series of Friedman tests run to revealing the priorities of banking expectations (table 4). These tests indicate that the expectations have not equal priorities. For example, Check related services is the most important expectations in pharmacies, speed and providing the banking services quickly is the most important expectation in the case of clinics and loan related expectations has the top priority for labs.

Tab. 4 - Status of the major expectations for each guild in the medical sector (Source: Authors)

\begin{tabular}{|c|c|c|c|c|c|c|c|c|c|}
\hline \multirow{2}{*}{$\begin{array}{c}\text { Main Expec- } \\
\text { tation }\end{array}$} & \multicolumn{3}{|c|}{ Pharmacy } & \multicolumn{3}{|c|}{ Clinic } & \multicolumn{3}{|c|}{ Laboratory } \\
\hline & Priority & MR & T-value & Priority & MR & T-value & Priority & MR & T-value \\
\hline $\begin{array}{c}\text { Interaction } \\
\text { with Special } \\
\text { Customers }\end{array}$ & 7 & 4.26 & 33.95 & 5 & 5.22 & 39.29 & 7 & 4.57 & 34.00 \\
\hline Relationship & 5 & 5.53 & 54.65 & 2 & 5.82 & 47.72 & 4 & 4.86 & 38.39 \\
\hline $\begin{array}{l}\text { Variety of } \\
\text { Banking } \\
\text { Services }\end{array}$ & 8 & 3.86 & 18.72 & 7 & 4.34 & 17.73 & 8 & 4.20 & 17.95 \\
\hline Access & 3 & 4.75 & 20.52 & 6 & 4.77 & 22.27 & 5 & 5.48 & 20.29 \\
\hline Speed & 4 & 5.87 & 47.28 & 1 & 5.84 & 36.79 & 3 & 4.92 & 42.70 \\
\hline Loans & 1 & 6.69 & 38.28 & 3 & 5.76 & 22.12 & 2 & 6.90 & 46.00 \\
\hline Check & 2 & 7.32 & 71.79 & 8 & 4.09 & 15.13 & 1 & 5.95 & 36.60 \\
\hline $\begin{array}{c}\text { Electronic } \\
\text { Banking } \\
\text { Features }\end{array}$ & 6 & 4.32 & 21.29 & 4 & 5.61 & 36.14 & 6 & 4.80 & 24.89 \\
\hline $\begin{array}{c}\text { Variety of } \\
\text { Electronic } \\
\text { Banking } \\
\text { Services }\end{array}$ & 9 & 2.40 & 1.48 & 9 & 3.55 & 16.48 & 9 & 3.33 & 9.98 \\
\hline $\begin{array}{c}\text { Friedman } \\
\text { Test Statistic }\end{array}$ & & $\begin{array}{l}g=0 .( \\
2=415\end{array}$ & & & $\begin{array}{l}g=0 / \\
2=162\end{array}$ & & & $\begin{array}{l}i g=0 . \\
2=132\end{array}$ & \\
\hline
\end{tabular}

Note: $M R=$ mean rank and the factor of variety of e-banking services in the Pharmacy Guild is of average importance.

\subsubsection{Segmenting medical guilds}

We used the K-Means algorithm as an unsupervised technique. For segmenting the guilds, we should first define the optimal number of clusters. Accordingly and based on the ward's method, it was revealed that the optimal number of clusters for segmenting would be 3 clusters. Table 5 shows the demographic profile of these three clusters. So we proceed with K-means by determining 3 for number of clusters. 
Tab. 5 - Demographic profile of clusters (Source: Authors)

\begin{tabular}{|c|c|c|c|c|c|}
\hline & $\begin{array}{c}\text { Demographic } \\
\text { variables }\end{array}$ & $\begin{array}{c}\text { Cluster } \\
1\end{array}$ & $\begin{array}{c}\text { Cluster } \\
2\end{array}$ & $\begin{array}{c}\text { Cluster } \\
3\end{array}$ & Total sum \\
\hline \multirow{3}{*}{ Guild } & Laboratory & 26 & 75 & 6 & 107 \\
\hline & Pharmacy & 80 & 72 & 5 & 157 \\
\hline & Clinic & 26 & 81 & 85 & 192 \\
\hline \multirow{2}{*}{ Gender } & Male & 115 & 198 & 55 & 368 \\
\hline & Female & 17 & 30 & 41 & 88 \\
\hline \multirow{4}{*}{ Age } & Under 40 years & 4 & 38 & 10 & 52 \\
\hline & $41-50$ & 11 & 147 & 55 & 213 \\
\hline & $51-60$ & 80 & 37 & 23 & 140 \\
\hline & Over 60 years & 37 & 6 & 8 & 51 \\
\hline \multirow{2}{*}{ Marital status } & Single & 0 & 1 & 2 & 3 \\
\hline & Married & 132 & 227 & 94 & 453 \\
\hline \multirow{4}{*}{ Experiences } & Under 10 years & 3 & 40 & 13 & 56 \\
\hline & 20 to 11 & 16 & 133 & 51 & 200 \\
\hline & 30.21 & 71 & 52 & 26 & 149 \\
\hline & Over 30 years & 42 & 3 & 6 & 51 \\
\hline \multirow{2}{*}{ Business property } & Rented & 23 & 134 & 55 & 212 \\
\hline & Ownership & 109 & 94 & 41 & 244 \\
\hline
\end{tabular}

Cluster 1: Traditional Segment. The first cluster consists of 132 practitioners equal to $28.95 \%$ of the sample. The first cluster was identified as the oldest one where most guilds had long-term experience. Pharmacy constituted majority of the cluster. Male made up a very high percentage of the cluster. 109 members of this cluster were owners of their business location. The cluster is named so because of two reasons: first, high importance of the check related factors, fast delivery of services and customer interaction which could be a sign of individuals' tendency to physical presence in the branches, and the other was low importance of the factors related to service variety and properties of e-banking services. The second reason for this could be the high age of the cluster.

Cluster 2: Modern Segment. Total number of this cluster members were 226 which equals to $50 \%$ of the whole sample. This cluster encompasses the younger respondents among the three clusters. Frequencies of the guilds were very similar to each other. Most respondents in this cluster $(n=134)$ had rented their business location. This led to the highest average importance of loans in this cluster. On the other side, check related expectations is in the second range of average importance. In this cluster, the average importance of all identified bank expectation were very high, and the difference in mean expectation identified in this cluster is minimal. Due to large differences in the importance of electronic banking features and services with two other clusters, this cluster named as "modern". 
Cluster 3: Low-expected clinics. The number of respondents in the third cluster is 96 which is equivalent to $21.05 \%$ of the sample. Percentage of females in this cluster is high compared to other clusters, and it can be described as the most feminine cluster. On the other hand, most respondents in this cluster were aged between 41 and 60 years. Regarding average expectations, factors related to check and the banking services were low. In this segment, factors relating to the characteristics of e-banking and relationship were at the highest mean importance; that is because clinics tend to take lower risks and seek to create better relationships with banks and financial institutions. Since this cluster had lower importance compared to other two clusters, we called it as "Low-expected medics".

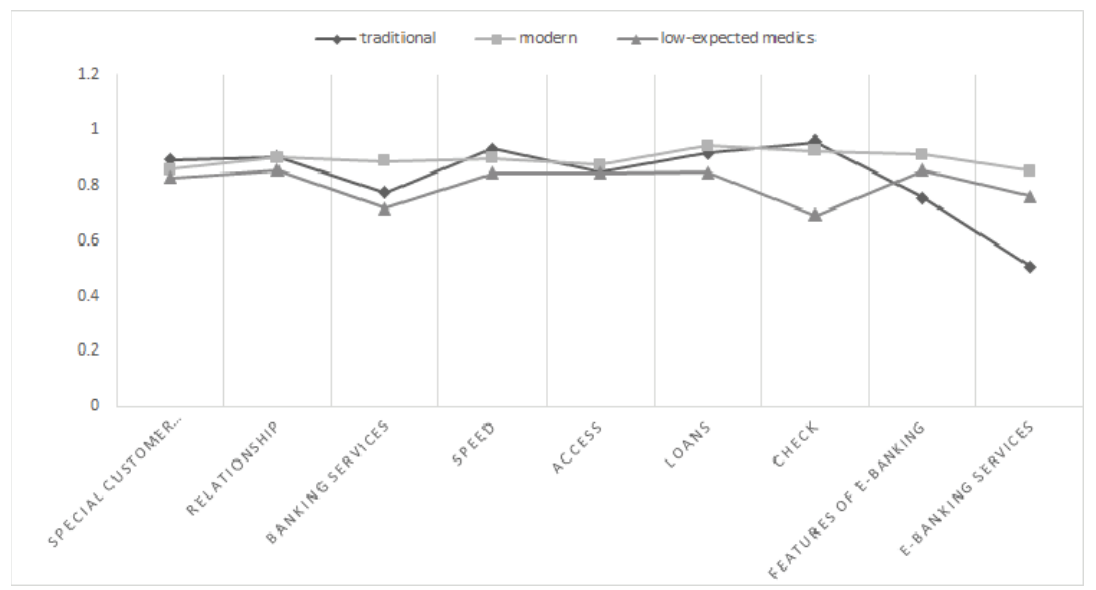

Fig. 1 - Average banking expectations among the three clusters identified (Source: Authors)

According to table 1, it is clear that importance of the following factors in all 3 clusters are nearly the same: interaction with special customers, relationship, accessibility, speed and loans; this is while factors like variety and features of e-banking services, check and bank services had significant difference among the clusters.

To answer the question of whether there is a significant differences between the identified clusters in terms of demographic variables Pearson's chi-square test used. Results showed (table 6) that we can express with very high confidence that the variables of type guild, gender, age, education, experience and acquiring businesses location are associated with the cluster membership. 
Tab. 6 - Testing independency of the identified clusters (Source: Authors)

\begin{tabular}{|c|c|c|c|c|c|c|c|}
\hline Bank expectations & Sig & d.f. & F & $\begin{array}{c}\text { Demographic } \\
\text { variables }\end{array}$ & Sig & d.f. & $\mathrm{X}^{2}$ \\
\hline $\begin{array}{c}\text { Interaction with } \\
\text { Special customer }\end{array}$ & 0.000 & 435 & 20.281 & Guild & 0.000 & 4 & 139.430 \\
\hline Relationship & 0.000 & 435 & 18.919 & Gender & 0.000 & 2 & 42.794 \\
\hline Banking Services & 0.000 & 435 & 90.727 & Age & 0.000 & 6 & 177.590 \\
\hline Speed & 0.000 & 435 & 35.529 & Marital status & 0.314 & 2 & 4.026 \\
\hline Access & 0.014 & 435 & 4.279 & Education & 0.000 & 6 & 31.434 \\
\hline Loans & 0.000 & 435 & 22.336 & History & 0.000 & 6 & 157.032 \\
\hline Check & 0.000 & 435 & 25.544 & Location & 0.492 & 8 & 7.423 \\
\hline $\begin{array}{c}\text { Features of } \\
\text { Electronic Banking }\end{array}$ & 0.000 & 435 & 100.937 & $\begin{array}{c}\text { Acquisition } \\
\text { of buildings }\end{array}$ & 0.000 & 2 & 63.155 \\
\hline $\begin{array}{c}\text { Electronic } \\
\text { Banking Services }\end{array}$ & 0.000 & 453 & 469.935 & & & & \\
\hline
\end{tabular}

To examine whether there is a significant difference between the averages of clusters' expectation factors or not, one-way ANOVA test was used. Considering the test results (table 6) and because the significance level of the tests on the identified expectation factors is below 0.001 (significance level of expecting accessibility is lower than 0.05 ), the following can be stated: The average of identified banking expectations among the 3 clusters difference is significant.

\section{DISCUSSION \& CONCLUSION}

This research tried to identify medical guilds from banks via mixed method design. In depth interview with the owner of guilds shoed 28 expectations from banks in nine main categories. Results indicated that although all three types of medical guilds have similar banking expectations but there is differences in their priorities. The only thing that should be noted is that the check related expectations, which has high importance in this sector, had received little attention in other studies, such as Narteh's study (2013).

Based on the results, it seems that banks should not consider the sector as the homogeneous market. The manifestation of this problem is shown in the identified clusters. In this regard, various factors cause differences in expectations of practitioners in the banking sector. For example, people in the rented buildings and offices have different expectation priorities compared to those having properties of their own. Even gender influenced the level of expectations, and it was observed that ladies had less expectations of check factor.

Banks should differentiate clinics from other medical guilds regarding design and providing of services. As the test of prioritizing expectations showed in clusters 1 and 2, laboratories and pharmacies mostly considered factors of loans and checks. For attracting such guilds, banks may act by offering loans through upstream organizations like the Association of Pharmacy and Medical Council which have punitive power. Accordingly, the risk of lost loans is reduced. 
Regarding the check factor, accrediting medical guilds with a high turnover seems one of the crucial necessities that any bank should offer for preserving this portion of its clients. Regarding clinics, as it can be seen in the third cluster (a cluster with the highest percentage of medics), as well as the results of the prioritizing expectations, factors of interaction and relationship had great importance and were along with the factors of respect and understanding customers stated by Marinkovic and Senic (2012). About practical use of this factor, we may refer to following of the branch heads of to begin and continue communications, training staff on how to deal with customers, and attracting and retaining the people in their bank.

About the accessibility, as seen in figure 1, the importance of this factor in all three clusters is roughly equal. So, it seems that the establishment of branches in crowded areas of the medical sector can be seen as a matter of necessity in attracting these people. It should also be considered that in this section, e-banking infrastructure including security, speed, and accuracy were more important than diversity of e-banking services. This view is aligned with Howcroft et al. (2007).

So, it seems that banks should improve the necessary infrastructure to attract medical practitioners to electronic banking. Expecting diversity of banking services in this sector was of the last priorities. This indicates that from the perspective of these guilds, banks still have not been able to provide differentiated services, and all banks offer the same services. In general, table 2 can be regarded as a summary of banking expectations in the medical sector.

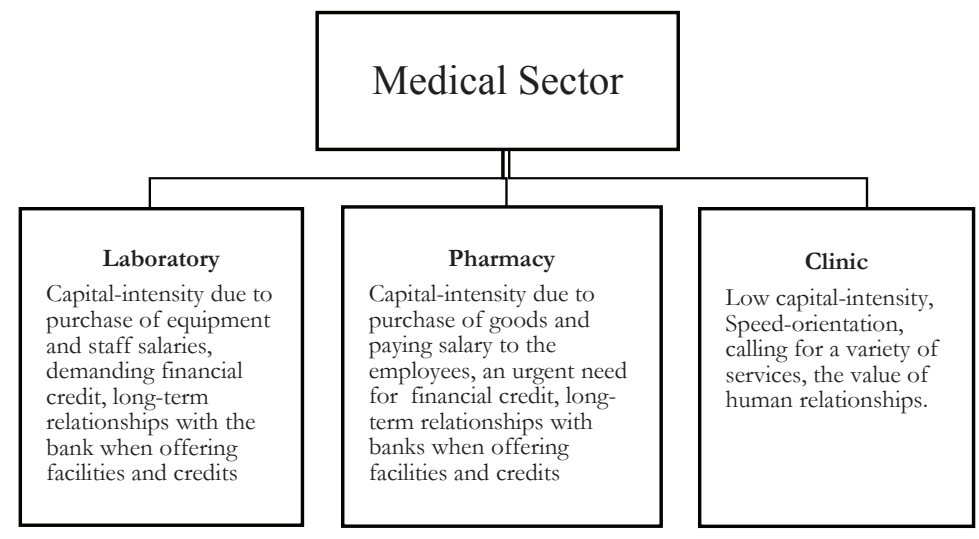

Fig. 2 - Expectation characteristics of guilds in the medical sector. (Source: Authors)

A limitation of this study could be that this research has only considered guilds established in Tehran city. Due to the different economic and social structures in other cities, especially in cities with low population, these expectations might be different.

Regarding future studies, researchers can conduct such research in this sector in other cities and even in other sectors. They may even do research on comparing bank expectations of retail customers. 


\section{References}

1. Adamson, I., Chan, K-M., \& Handford, D. (2003). Relationship Marketing: Customer Commitment and Trust as a Strategy for the Smaller Hong Kong Corporate Banking Sector. International Journal of Bank. Marketing, 21(6/7), 347-58. doi:10.1108/026523203104984 92

2. Alfansi, L., \& Sargeant, A. (2000). Market Segmentation in Indonesian Banking Sector: The Relationship between Demographics and Desired Customer Benefits. International Journal of Bank Marketing, 18(2), 64-74. doi:10.1108/02652320010322976

3. Anderson, E. W. (1994). Cross-category Variation in Customer Satisfaction and Retention. Marketing Letters, 4(1), 19-30. doi:10.1007/bf00993955

4. Azizi, S., Hosseinabadi, V., \& Balaghi, M. (2014). Segmentation of Internet Banking Users Based on Expectations: A Data Mining Approach. Journal of Information Technology Management, 6(3), 419-434.

5. Beane, T.P., \& Ennis, D.M. (1987). Market Segmentation: A Review. European Journal of Marketing, 21(5), 20-42. doi:10.1108/eum0000000004695

6. Cheron, E.J., Mc'Tavish, R., \& Perrien, J. (1989). Segmentation of Bank Commercial Markets. International journal of bank marketing, 7(6), 25-30. doi:10.1108/eum00000000014

7. Gremler, D.D., \& Gwinner, K.P. (2000). Customer- Employee Rapport in Service Relationships. Journal of Service Research, 3, 82-104. doi:10.1177/109467050031006

8. Harrison, T. (2000). Financial Service Marketing. Great Britain: Prentice Hall.

9. Howcroft, B., Durkin, M., Armstrong, G., \& Emerson, E. (2007). Small Business-Bank Relationships and the Role of Internet Banking. Service Industries Journal, 27(7), 947-961. doi:10.1080/02642060701570784

10. Kotler, P. (2006). Marketing Management: A Framework. New Jersey: Prentice Hall.

11. Kotler, P., \& Armstrong, G. (2010). Marketing Principles. Isfahan, Iran: Amukhteh Pub.

12. Kotler, P., \& Keller, K.L. (2012). Marketing Management (14th ed.). New Jersey: Prentice Hall.

13. Lam, R., \& Burton, S. (2006). SME Banking Loyalty (and disloyalty): A Qualitative Study in Hong Kong. International Journal of Bank. Marketing, 24(1), 37 - 52. doi:10.1108/026523206 10642335

14. Lundahl, M., Vegholm, F., \& Silver, L. (2009). Technical and Functional Determinants of Customer Satisfaction in the Bank-SME Relationship. Managing Service Quality, 19(5), 581 - 594. doi:10.1108/09604520910984382

15. Machauer, A., \& Morgner, S. (2001). Segmentation of bank customers by expected benefits and attitudes. International Journal of Bank. Marketing, 19(1), 6-18. doi:10.1108/0265232011036 6472

16. Madill, J.J., Feeney, L., Riding, A., \& Hainess, G.H. (2002). Determinants of SME owners' Satisfaction with Their Banking Relationships: a Canadian Study. International Journal of Bank Marketing, 20(2), 86-98. doi:10.1108/02652320210419698 
17. Marinkovic, V., \& Senic, V. (2012). Analaysis of Service Quality Elements in Corporate Banking. Economic Horizons, 14(1), 15-24.

18. Narteh, B. (2013). SME Bank Selection and Patronage Behaviour in the Ghanaian Banking Industry. Management Research Review, 36(11), 1061-1080. doi:10.1108/mrr-06-2012-0147

19. Nielsen, J.F., Terry, C., \& Trayler, R.M. (1998). Business Banking in Australia: A Comparison of Expectation. International Journal of Bank Marketing, 16(6), 253-263. doi:10.11 08/02652329810241393

20. Parasuraman, A., Zeithmal, V.A., \& Berry, L.L. (1988). SERVQUAL: A Multiple-item Scale for Measuring Consumer Perception of Service Quality. Journal of Retailing, 64(1), 12-40.

21. Punj, G.N., \& Stewart, D.W. (1983). Cluster Analysis in Marketing Research: Review and Suggestion. Journal of Marketing Research, 20, 134-148. doi:10.2307/3151680

22. Reichheld, F.F. (1996). The Loyalty Effect. Boston M.A: Harvard Business School Press.

23. Sekaran, U. (2003). Research Methods for Business: A Skill Building Approach. New York: John Wiley \& Sons.

24. Smith, W. (1956). Product Differentiation and Market Segmentation as Alternative Marketing Strategies. Journal of Marketing, 21, 3-8.

25. Wang, Y.S., \& Liao, Y.W. (2007). The Conceptualization and Measurement of M-commerce User Satisfaction. Computers in Human Behavior, 23(1), 381-398. doi:10.1016/j.chb.2004.10.017

26. Weinstein, A. (2004). Handbook of Market Segmentation. New York: The Haworth Press.

27. Zineldin, M. (1995). Bank-Company Interactions and Relationships: Some Empirical Evidence. International Journal of Bank Marketing, 7(4), 29-32.

\section{Contact information}

Shabriar Azizi

Associate Professor of Marketing

Shabid Beheshti University, Tehran, Iran

E-mail:azizi.sbu@gmail.com

\section{Vahid Hosseinabadi}

Phd Student of Business Policy Making

Shahid Beheshti University, Tehran, Iran

E-mail:hosseinabadi.vba@gmail.com 